Başvuru Tarihi: 28.07.2017 Received Date: 28.07.2017

Yayına Kabul Tarihi: 27.12.2017 Accepted Date: 27.12.2017

Yayınlanma Tarihi: 29.01.2018 Published Date: 29.01.2018
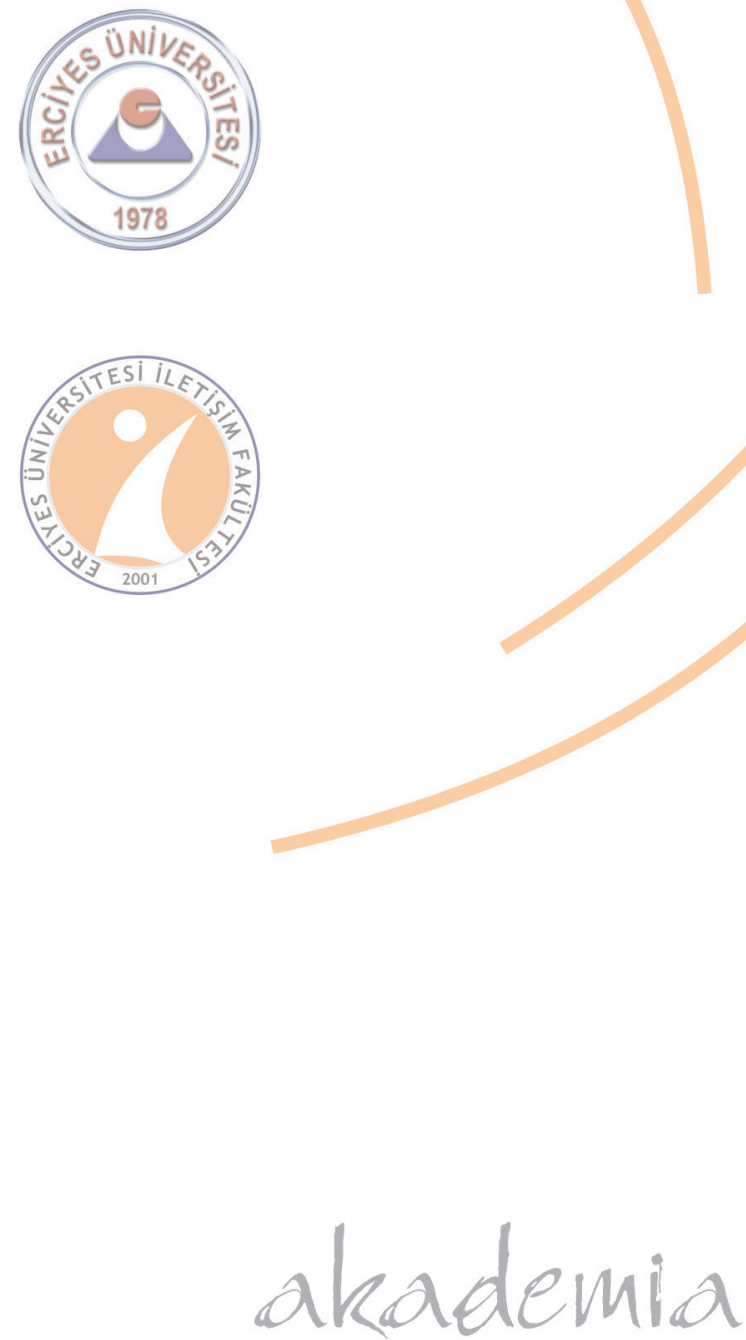
ISSN:1308-3198

Erciyes İletişim Dergisi akademia 2018

Cilt (Volume): 5, Say1 (Number): 3, (40-52)
Cenge ATEŞ (Yüksek Lisans Öğrencisi)

Manisa C. B. Üni. Spor Bilimleri Fakültesi cenge.ates@hotmail.com Yavuz YILDIZ (Doç. Dr.)

Manisa C. B. Üni. Spor Bilimleri Fakültesi yavyildiz@hotmail.com

Kadir YILDIZ (Yrd. Doç. Dr.)

Manisa C. B. Üni. Spor Bilimleri Fakültesi

kadir.yildiz@cbu.edu.tr

\section{PROFESYONEL BASKETBOL ve VOLEYBOLCULARIN ANTRENÖR İLETISTIM BECERİ DÜZEYLERİ ALGISI ve SPORCULARIN KAYGI DÜZEYLERININ ARAŞTIRILMASI}

\section{$\ddot{\mathbf{O} z}$}

Bu çalışmada, profesyonel basketbol ve voleybolcuların algıladıkları antrenör iletişim becerisi ile sporcuların kaygı durumu üzerinde etkili olabilecek değişkenlerin incelenmesi amaçlanmıştır. Araştırmanın çalışma grubu, rastgele örneklem yöntemiyle belirlenen 235 sporcudan (106 kadın, 129 erkek) oluşmaktadır. Veri toplama aracı olarak Antrenör İletişim Beceri Ölçeği (Yılmaz 2008) ve Sürekli Kaygı Ölçeği (Spielberger ve diğerleri, 1970) kullanılmıştır. Verilerin analizinde; korelasyon ve regresyon testleri kullanılmıştır. Cinsiyet, medeni durum, spor yapma süresi ve mevcut antrenör ile çalışma süresinin antrenör iletişim becerisi düzeyi algısı üzerinde etkisi olduğu; cinsiyet ve eğitim düzeyinin ise sporcuların sürekli kaygı düzeyi üzerinde etkisi olduğu saptanmıştır. Sonuç olarak, 22 yı1 ve üzeri spor yapma süresi olan sporcuların 7 yıl ve altı spor yapma süresi olan sporculara göre antrenörlerinin iletişim becerisini daha yüksek seviyede algıladığı; kadın sporcuların erkek sporculara göre, voleybolcuların ise basketbolculara göre kayg1 düzeylerinin daha yüksek olduğu tespit edilmiştir. Amatör sporcular ve farklı branşların dahil edildiği, profesyonel ve amatör sporcuların antrenör iletişim becerisi algısı ve kaygı düzeylerine yönelik olarak yapılacak araştırmalarda farklı sonuçlar elde edilebilir.

Anahtar Kelimeler: Spor, Sporcu, Antrenör, İletişim, Kayg1.

\section{ANALYSIS OF TRAINER COMMUNICATION SKILL LEVEL PERCEPTION OF THE PROFESSIONAL BASKETBALL AND VOLLEYBALL PLAYERS AND OF ANXIETY LEVEL OF THESE ATHLETES}

\section{Abstract}

In this study, it is aimed to analyze the variables which might have effects on trainer communication skills perceived by professional basketball and volleyball players and on their anxiety level. The study group of this research consists of a total of 235 athletes (106 female and 129 male) determined by random sampling. As the data collecting tool, Trainer Communication Skill Scale (Y1lmaz 2008) and Trait Anxiety Scale (Spielberg et.al 1970) have been used. In the analysis of the data, correlation and regression tests have been used. It is found that while gender, marital status, the length of playing sports and the length of working with their current trainers have effects on the level of trainer communication skill levels, gender and educational level have effects on trait anxiety levels of the athletes. As a result, when compared to the athletes with 7 and minus years of experience, the athletes with 22 and plus years of experience perceive trainer communication skill in a higher level; and it is found that when compared to male athletes, the female athletes and when compared to basketball player, the volleyball players have a higher level of anxiety levels. In the future research where amateur athletes and different branches of sports are included and where analysis related to trainer communication skill perception and trait anxiety levels of professional and amateur athletes are carried out, different results might be obtained.

Keywords: Sports, Athlete, Trainer, Communication, Anxiety. 


\section{Giriş}

Spor yapılış amacı doğrultusunda, tüm dünyada yarışma, toplum sağlığı, rehabilitasyon ve eğitim- öğretim olmak üzere dört başlık altında gerçekleşmektedir (Çetin, 2013, 1). Bu doğrultuda spor, kişisel gelişim, toplumsallaşma, çalışma hayatına yaptığı olumlu etki ile birlikte bireylerin bedensel ve zihinsel gelişimine katkıda bulunan bir sosyal olay olarak da ifade edilebilmektedir (Doğan, 2007, 9-14). Diğer yandan spor, insan yaşamında ve toplum sağlığında yer alan önemli bir olaylar kümesi olarak da tanımlanabilir (Aktaran: Atasoy ve Kuter, 2005, 14).

Tarihi boyunca kendisi ve çevresiyle olan ilişkilerinde sürekli olarak bir iletişim ağının içinde bulunan insanoğlunun, kendisi ve başkalarıyla olan etkileşiminin gücünü belirleyen iletişim unsuru, hem kişisel hem de toplumsal bir süreçtir. Bir kişinin bir bilgiyi anlaşılır biçimde başka kişilere aktarması veya bireyler arası etkileşimi mümkün kılan bir sistemdir (Bahar, 2012, 2). Duygularını, düşüncelerini, hissettiklerini karşısındakine aktarma isteği duyan insanoğlunun, konuşma ve yazma eğilimine girmesi ve bu dürtülerini konuşma ve dinleme aracılığ ile açıklığa kavuşturmak istemesi iletişim olgusunu ortaya çıkarmıştır (Çetinkaya, 2011, 567-568). Bu olgu neticesinde iletişim süreci, düşüncelerin belirli objelerle anlatıldı̆̆ 1 bir verici ve bu objeleri çözümleyen ve algılayan bir alıcıyı gerektirir. Bu süreçte vericinin düşüncelerinin alıcıya ulaştırılıp alıcıda bir anlam kazanması amaçlanmaktadır (Bilgin, 2010, 111).

Günümüzde iletişim kavramına ilişkin olarak birçok tanım yapılagelmiştir. Bu tanımların bazılarında iletişim kavramı; bilgi, düşünce, hisler, beceriler vb. unsurların simgelerin kullanımı aracılığıyla bir iletim çabası, yaşanılan çevreyi algılamaya yönelik sarf edilen gayretlerin ayırt edici ve örgütleyici bir şekilde ifade edebilme yeteneği, bilgi üretimi ve üretilen bilginin paylaşımını barındıran bir süreç olarak ifade edilmektedir (Mutlu, 2012, 148-149). Bununla birlikte Bahar'a (2012, 5-6) göre yalnızca haberleşme, mesaj, düşünce ve bilgi paylaşımı olarak nitelendirmek iletişimi dar açıdan değerlendirmektir. İletişim kaynaktan hedefe yapılan bilgi transferidir ve iletişim kurmanın bilgi, motivasyon, kontrol ve heyecanlandırma gibi dört temel fonksiyonu vardır.

İletişim; sözlü, yazıl1, sözsüz iletişim biçimlerinde olabilir (Demirtaş, 2010, 417). Dökmen (1994), sözlü iletişimi, kişilerarası iletişim içerisinde sınıflandırmıș ve kişilerarası iletişimi kaynağın da alıcının da insan olduğu, insanlar arasında gerçekleştirilen bir iletişim çeşidi olarak tanımlamıştır. Sözlü iletişim, dille iletişim ve dil ötesi iletişim olmak üzere iki alt boyutta yer almaktadır. Bireylerin karş11ıklı olarak gerçekleştirdiği konuşmalar 'dille iletişim', iletişim esnasında konuşmalardaki sesin nitelik, hız, ton, şiddet ve vurgusu ise 'dil ötesi iletişim' olarak nitelendirilmektedir. Dille iletişimde bireyler üretilen bilgiyi karşılıklı olarak birbirleri ile paylaşarak anlamdırırlar. Dille iletişimde söylenen sözler, mesajlar önemliyken, dil ötesi iletişimde söylenen sözlerden ziyade nasıl söylendiği, söyleniş biçimi önem arz etmektedir (Aktaran: Işık, 2013, 6).

Sözsüz iletişim ise, insanların konuşma haricindeki araçlarla gerçekleştirdiği bir iletişim türüdür (Mutlu, 2012, 288). Sözsüz iletişimde insanlar; yüz, göz, el kol hareketlerinin yanı sıra giyim kuşam, seçilen renkler, mekânsal düzenlemeler, dekorasyon vb. unsurlar dâhilinde de bir etkileşimde bulunurlar. Sözsüz iletişimin önemli bir kısmını oluşturan jestler, mimikler, giyim tarzı gibi insan bedeni aracılı iletişim, beden dili olarak da adlandırılmaktadır (Güngör, 2013, 38). Diğer bir iletişim türü olan yazılı iletişim ise diğer iletişim türlerine göre daha detaylıdır. Ayrıntıların önem taşıdığı durumlarda genellikle tercih edilir. Karşılıklı duygu ve fikir alışverişlerinin geri bildirimi güçleştirmesine karşın, iletilen mesaj üzerinde daha etkin ve verimli biçimde düşünebilmeye olanak sağlamaktadır (Şahin, 2007, 88).

Son yıllarda iletişim, beden dili uygulamaları gibi konuların eğitim ve seminer konseptlerinde uyarlanarak ticari kazanç aracı getirilmesiyle birlikte asıl iletişimin beden dili olduğu fikrini savunan görüşlere karşın, sözlü ve sözsüz iletişim arasında bir önem sıralamasına gidilmeden iletişim esnasında bu iki iletişim türünün birlikte doğru ve tutarlı kullanımıyla iletişimde bulunan kişiler arasında anlam kargaşasını en aza indirgeyerek daha güçlü bir iletişim ağı kurulmasına imkân tanıyacaktır (Güngör, 2013, 36-38). 
Bireylerin ve toplumların var oluş gerekçelerinde önemli bir paya sahip olan iletişim olgusu, aynı zamanda toplumsal bütünlüğü de sağlayan bir insan etkinliğidir. Toplumsal yaşamın olmazsa olmaz bir ögesi olarak hayatımızda yer alan spor ve bu bağlamda spor etkinlikleri de, her yaş ve kesime hitap edebilecek özellik taşımakta, her geçen gün çeşitlenerek artan spor etkinlikleri ile birlikte toplumsal iletişime ve birlikteliğe de katkı sağlamaktadır. Buna bağlı olarak iletişim ve spor, sosyal hayat içerisinde büyük önem taşıyan ve yön veren kavramlardır (Abakay ve Kuru, 2011a, 126).

Günümüzde iletişim kavramının farklı fonksiyon ve özellikleriyle sportif etkinlikler içerisinde yer aldığı bilinmektedir. Bu doğrultuda sporcular, antrenörler ve sportif etkinlikler içerisinde yer alan diğer kişi ve kuruluşlar başarıya ulaşma yolunda birliktelik ve düzen içinde çaba sarf etmektedir. Bu düzen dâhilinde iletişimi gerçekleştirenler ise saha içerisindeki sporcular ve antrenörlerdir (Kabadayı, 2010, 87).

İletişimi etkin biçimde kullanabilme yeteneği, insan ilişkileri ve meslek alanındaki ilişkilerde önemli rol oynamaktadır. İletişimin toplumsal ve örgütsel yaşamdaki başarılı ilişkiler için arz ettiği önem ile bireysel ve mesleki hayatta başarılı olabilmek adına sahip olduğu hayati önem, insan gruplarını yönetmek için de gereklidir (Singer, 1990, 214-220). Buna bağlı olarak sportif alanda elde edilebilecek başarılar için, takım içerisinde yer alan antrenör- sporcu arası ilişkinin de önemi büyüktür. Takım sporlarında doğru taktik ve yöntemlerin antrenör tarafından sporcuya doğru ve anlaşılır biçimde aktarımı ve etkili bir iletişimin olması, takımın başarısına katkı sağlayacağı söylenebilir.

Spor sahalarında takım içerisinde kurulan iyi ilişkiler, her oyuncunun pozitif düşüncesini tamamlayan özel bir enerji haline gelmektedir (İşler, 2012, 136-143). Takım içerisinde genellikle antrenörlerin lider pozisyonunda bulunduğu düşünüldüğünde; başarıya yönelik olumlu katkılar alabilmek için antrenörlerin, sporcuların kendisiyle ve kendi aralarında olan ilişkilerinde özen göstermeleri gerektiği ifade edilmiştir (Abakay ve Kuru, 2013b, 22). Antrenör ve sporcu birlikteliğinde her iki taraf da birbirinden etkilenme durumundadır. Sporcu, antrenörün donanım ve birikimlerinden istifade etme eğiliminde bulunurken; antrenör de, sporcunun gösterdiği performansta kendi yeterliğini ve maharetlerini aracı olarak kullanma gayretindedir. Bu sebeple sporcu ve antrenör, başarıya ulaşma yolunda bir etkileşim içinde bulunma güdüsü hissederler (Selağzı ve Çepikkurt, 2014, 12-13).

Spor ortamında antrenörlerin kullandığı beden dili ve sergilediği liderlik davranış tipleri de sporcularla arasındaki ilişkinin gücünü belirleyen unsurlardandır. Bu bağlamda, antrenörler takım içindeki en baskın güç konumundadır ve otoritenin kaybolması durumunda sporcular ve antrenörler üzerinde ön plana çıkan en önemli faktörlerden birisi kaygıdır (Yetim ve Cengiz, 2012, 125-127). Kayg1; insanı gelecekle alakalı üzen, sıkıntılı bir duruma iten, güvensizlik duygusu ile karşı karşıya bırakan (Aktaran: Coşkun ve Akkaş, 2009, 215); üzüntü, sıkıntı, korku, başarısızlık duygusu, acizlik, sonucu bilememe, yargılanma duygularından bir veya birçoğunu içerebilen bir heyecan durumudur (Cüceloğlu, 1999, 440). Spielberger (1971), Cattell ve Scherer (1958; 1961)'in faktör analizi ile ortaya koyduğu çalışmalarında, "durumluk kaygı" ve "sürekli kayg1" olmak üzere iki türde kaygı çeşidi olduğunu belirtmiştir (Aktaran: Büyüköztürk, 1997, 453). Durumluk kaygı, içinde bulunulan çevre koşullarına bağlı olarak şiddetini gösteren, geçici bir stres durumu iken; sürekli kayg1, strese sebep olan etmenlerin yoğunluğunun artması ile birlikte süreklilik kazanmasıdır (Civan ve diğerleri, 2010, 195).

İnsanın en temel ihtiyaçlarından birisi olan iletişim olgusu; aile, arkadaş, yakın çevre ve iş dünyası içinde kurulan ve pozitif boyutta sürdürülen ilişkiler içinde psikolojik bir destek kaynağıdır. İlişkinin kalitesi, kaygı düzeyini belirlemede önemli rol oynar (Tosun, 2014). Bu doğrultuda etkin iletişimin kullanımı bireyin bulunduğu iletişim ortamında kaygı düzeyini belirleyen ana unsurlardandır. Dolayısıyla spor ortamında kullanılan iletişim türünün de ilişkilerde etkileyici konumda olduğunu söylemek mümkündür. 
Sporcuların antrenörleri ile kurdukları iletişim düzeyi ve kaygı düzeylerinin takımın alacağı sportif sonuçlara etki edebilecek önemli etmenler olduğu düşünülmektedir. Araştırmada, sporcuların gözünden antrenörlerinin iletişim beceri düzeyi ve sporcuların kaygı düzeylerinin belirlenerek, bu değişkenler üzerinde etkili olabilecek etmenlerin incelenmesi amaçlanmıştır.

\section{Yöntem}

\subsection{Araştırmanın Modeli}

Araştırmada, nicel araştırma yöntemlerinden genel tarama tekniği tercih edilmiştir. Genel tarama modeli, çok sayıda elemandan oluşan evren hakkında genel bir yargıya varmak için evrenden alınan örneklem üzerinde yapılan yöntemdir (Karasar, 2014: 79).

\subsection{Araştırma Problemi}

Antrenör ve sporcu arasında kurulan iletişimin ve sporcuların kaygı düzeyinin spor ortamındaki yeri ve önemi nedir?

Antrenör iletişim becerisi ve sporcuların kaygı düzeyi arasındaki ilişkinin, daha etkin ve verimli bir takım yönetiminde yeri var mıdır?

Antrenör iletişim becerisi ve sporcuların kaygı düzeyinin takım başarısının sağlanmasında yeri var midır?

$\mathrm{Bu}$ konudaki sorulara araştırma çerçevesinde yanıtlar aranmaktadır.

\subsection{Araştırmanın Sınırlılıkları}

Mevcut araştırmada Manisa, İzmir, İstanbul, Bursa ve Tekirdağ illerinde yer alan takımların çalışma grubunu oluşturması, diğer bölge ve illerde yer alan takımlara ulaşılamamış olması araştırmanın sınırlılığı olarak kabul edilmiştir.

\section{4 Çalışma Grubu}

Araştırmanın evreni, 2015-2016 sezonunda Türkiye'deki profesyonel düzeydeki basketbol ve voleybol liglerindeki sporculardan oluşmaktadır. Bu liglerde yer alan 59 erkek, 69 kadın basketbol takımı ile 96 erkek, 102 kadın voleybol takımında mücadele eden; yaklaşık 1600 basketbolcu (900 erkek, 700 kadın) ve 1950 voleybolcu (950 erkek,1000 kadın) araştırmanın evrenini temsil etmektedir. Araştırmada, zaman ve ulaşım kısıtlılığından dolayı kolayda örneklem alma yöntemi tercih edilmiştir. Manisa, İzmir, İstanbul, Bursa ve Tekirdağ illerinde mücadele eden takımlardan araştırmaya gönüllü olarak katılan 129'u erkek ve 106'sı kadın, toplamda 235 sporcu araştırmanın örneklem grubunu oluşturmaktadır.

\subsection{Veri Toplama Araçları}

Araştırmada veri toplama aracı olarak araştırmacılar tarafından hazırlanılan Kişisel Bilgi Formu ile Antrenör İletişim Beceri Ölçeği ve Sürekli Kaygı Ölçeği kullanılmıştır.

Kişisel Bilgiler; Yaş, cinsiyet, medeni durum, eğitim düzeyi, spor branşı, spor yapma süresi ve mevcut antrenör ile çalışma süresini içeren demografik özellikler çalışmada veri toplama aracına dahil edilmiştir.

Antrenör İletişim Beceri Ölçeği (AİBÖ): Yılmaz (2008) tarafindan geliştirilen AİBÖ, 48 maddeden oluşan 5'li likert tipi yapıya sahip bir ölçektir. Ölçek değerlendirilmesi toplam puan üzerinden yapılmaktadır. Elde edilen puanlar neticesinde "Antrenör İletişim Becerisi" 1.00-1.79 arasında ise etkisiz, 1.80-2.59 arasinda ise zayıf, 2.60-3.39 arasinda ise vasat, 3.40-4.19 arasinda ise etkili fakat geliştirilmesi gereken ve 4.20-5.00 arasında ise üst düzeyde etkili olarak değerlendirilerek yorumlanmıştır. Orijinal çalışmada madde toplam korelasyonları .44 ve .86 ; alfa katsayısı ise .95 olarak tespit edilirken, mevcut araştırmada madde toplam korelasyonları .50 ve .76; alfa katsayısı ise .97 olarak bulunmuştur. Yapılan testlerden hareketle, “Antrenör İletişim Beceri Ölçeği”nin geçerli ve güvenilir bir ölçek olduğu, mevcut araştırmada istenen ölçüm özelliklerini sağladığı görülmüştür. 
Sürekli Kaygı Ölçeği (SKÖ): Spielberger, Gorsuch ve Luschene (1970) tarafindan geliştirilen, Öner ve Le Compte (1974-1977) tarafından Türkçe uyarlama çalışması yapılan durumluk ve sürekli kaygı ölçeğinin, 20 maddeden oluşan Sürekli Kaygı Ölçeği kullanılmıştır. Ölçek 4'lü likert tipi bir yapıya sahiptir. Ölçekte doğrudan ifadeler ile tersine çevrilmiş ifadeler yer almaktadır. Olumlu duyguları belirten tersine çevrilmiş ifadelerin puanlanmasında, 1 ağırlık değerindeki ifadeler 4'e, 4 ağırlık değerindeki ifadeler ise 1'e dönüştürülür. Olumsuz duyguları belirten doğrudan ifadelerde, 4 ağırlık değerindeki yanıtlar yüksek kaygıyı gösterir. Tersine çevrili ifadelerde ise; 4 ağırlık değerindeki cevaplar düşük kaygı seviyesini, 1 ağırlık değerindeki cevaplar yüksek kaygı seviyesini işaret eder. "Sürekli Kayg1 Ölçeği”nde 1., 6., 7., 10., 13., 16. ve 19. maddeler tersine çevrilmiş ifadelerdir. 'Sürekli Kaygı Ölçeği’ puanlamasında, doğrudan ifadelerin puanından çıkartılan tersine çevrilmiş ifadelerin puanına 35 sabit puan eklenir. Ölçekten ortaya çıkan puan değerleri 20 ile 80 arasında değişkenlik gösterebilmektedir. Elde edilen puanlar neticesinde, yüksek puan yüksek kaygı düzeyini, düşük puan düşük kayg1 düzeyini göstermektedir. Ölçeğin faktör yükleri, .51 ile .70 arasında, Cronbach Alpha Katsayısı ise .82 olarak bulunmuştur. Bu doğrultuda ölçeğin geçerlik ve güvenirlik değerlerinin yüksek olduğu görülmektedir.

\subsection{Verilerin Toplanması}

Mevcut araştırma için düzenlenen ölçekler, antrenman öncesi ve sonrasında sporculara araştırmacılar tarafından ön bilgilendirme yapılarak doldurturulmuştur. Antrenman öncesi ve sonrasında sporcuların yorgunluk faktörüne bağlı olarak sporcuların ölçekleri algılama düzeyinde meydana gelebilecek farklılıklar, araştırmada kısıtlılık olarak kabul edilmiştir.

\subsection{Verilerin Analizi}

Elde edilen verilerin istatistiksel hesaplamalarında IBM SPSS 20 paket programı kullanılmıştır. İstatistiksel gösterim olarak ise frekans ve aritmetik ortalama sunulmuştur. Örneklem sayısı 50'den fazla olduğu için normallik sınaması Shapiro-Wilk Testi değerleriyle yapılmış ve veri setinin normal dağılıma uygun olmadığı görülmüştür. İstatistiksel değerlendirmelerde ise Mann Whitney-U Testi, Kruskal Wallis Testi, Korelasyon ve Çoklu Regresyon Analizinden faydalanılmıştır. Verilerin değerlendirilmesinde anlamlılık düzeyi $p<.05$ kabul edilmiştir.

\subsection{Araştırmanın Hipotezleri}

$\mathrm{Bu}$ araştırmada, aşağıda yer alan hipotezlere ilişkin yanıtlar aranmaktadır.

H1: Sporcuların yaş değişkenine göre, AİBÖ ve SKÖ farklılaşmaktadır.

H2: Sporcuların cinsiyet değişkenine göre, AİBÖ ve SKÖ farklılaşmaktadır.

H3: Sporcuların medeni durum değişkenine göre, AİBÖ ve SKÖ farklılaşmaktadır.

H4: Sporcuların eğitim durumu değişkenine göre, AİBÖ ve SKÖ farklılaşmaktadır.

H5: Sporcuların spor branşı değişkenine göre, AİBÖ ve SKÖ farklılaşmaktadır.

H6: Sporcuların spor yapma süresi değişkenine göre, AİBÖ ve SKÖ farklılaşmaktadır.

H7: Sporcuların mevcut antrenörleri ile çalışma süresi değişkenine göre, AİBÖ ve SKÖ farklılaşmaktadır.

H8: AİBÖ ve SKÖ arasında negatif yönlü bir ilişki vardır.

H9: Demografik değişkenlerin, AİBÖ ve SKÖ üzerinde etkisi vardır.

\section{Bulgular}

Profesyonel basketbol ve voleybol antrenörlerinin iletişim beceri düzeyleri ve sporcuların kaygı düzeyine etki eden değişkenlerin belirlenmesi amacıyla yapılan bu çalışmaya yaş ortalaması 22,13 $\pm 5,24$ olan 129 erkek sporcu ile 20,96 $\pm 5,00$ olan 106 kadın; toplamda 235 sporcu katılmıştır. 
Tablo 1. Sporcuların Demografik Bilgilerine Göre Frekans ve Yüzde Dă̆llımları

\begin{tabular}{|c|c|c|c|}
\hline \multicolumn{2}{|c|}{ Değişkenler } & f & $\%$ \\
\hline \multirow{5}{*}{ Yaş } & 18 ve altı & 87 & 37.0 \\
\hline & $19-23$ & 83 & 35.3 \\
\hline & $24-28$ & 40 & 17.0 \\
\hline & $29-33$ & 16 & 6.8 \\
\hline & 34 ve üstü & 9 & 3.8 \\
\hline \multirow{2}{*}{ Cinsiyet } & Erkek & 129 & 54.9 \\
\hline & Kadın & 106 & 45.1 \\
\hline \multirow{2}{*}{ Medeni Durum } & Evli & 25 & 10.6 \\
\hline & Bekâr & 210 & 89.4 \\
\hline \multirow{3}{*}{ Eğitim Durumu } & Ortaöğretim & 57 & 24.3 \\
\hline & Lisans & 162 & 68.9 \\
\hline & Lisansüstü & 16 & 6.8 \\
\hline \multirow{2}{*}{ Spor Branşı } & Basketbol & 126 & 53.6 \\
\hline & Voleybol & 109 & 46.4 \\
\hline \multirow{4}{*}{ Spor Yapma Süresi } & 7 yıl ve altı & 57 & 24.3 \\
\hline & $8-14$ yıl & 123 & 52.3 \\
\hline & $15-21$ yıl & 46 & 19.6 \\
\hline & 22 yıl ve üstü & 9 & 3.8 \\
\hline \multirow{4}{*}{$\begin{array}{l}\text { Mevcut Antrenör ile } \\
\text { Çalışma Süresi }\end{array}$} & 12 ay ve altı & 130 & 55.3 \\
\hline & 13-36 ay & 72 & 30.6 \\
\hline & $37-60$ ay & 17 & 7.2 \\
\hline & 60 ay ve üstü & 16 & 6.8 \\
\hline
\end{tabular}

Tablo 1 incelendiğinde araştırmaya 129 erkek, 106 kadın sporcu katılmıştır. Bu sporculardan 210 kişinin medeni durumlarının bekâr olduğu ve sporcuların büyük bir çoğunluğunun eğitim düzeyinin lisans seviyesinde $(162 ; \% 68,9)$ olduğu görülmektedir. Araştırmaya katılan 235 sporcunun büyük bir çoğunluğunun spor yapma süresinin 8-14 yıl arası (123; \%52,3) ve mevcut antrenörleri ile çalışma süresinin 1 yıl ve altında (130; \%55,3) olduğunu söylemek mümkündür (Şekil 1).

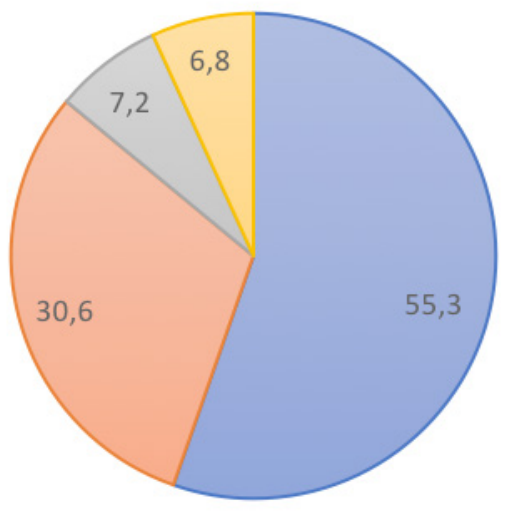

\section{$\square 12$ ay ve altı $\square 13-36$ ay $\square 37-59$ ay $\square 60$ ay ve üstü}

Şekil 1. Sporcuların Antrenörleriyle Çalışma Zamanı Dağılımı 
Tablo 2. Antrenör İletişim Beceri Ölçeği (AIBÖ) ve Sürekli Kaygl Ölçeği (SKÖ) Tanımlayıcı Istatistikleri

\begin{tabular}{|c|c|c|c|c|c|}
\hline Değişkenler & $\mathrm{N}$ & Min. & Max. & X & S.S \\
\hline AïBÖ & 235 & 99 & 240 & 196.17 & 30.48 \\
\hline SKÖ & 235 & 29 & 68 & 45.91 & 6.78 \\
\hline
\end{tabular}

Tablo 2 incelendiğinde AİBÖ minimum değeri 99, maksimum değeri 240, ortalama puanı ise 196,17'dir. Ortalama değer 48 maddeye bölündüğünde ortaya çıkan 4,08 ortalama madde puanı antrenörlerin etkili fakat geliştirmesi gereken iletişim becerilerine sahip olduğunu göstermektedir. Sporcuların SKÖ değerleri incelendiğinde ise, minimum değeri 29, maksimum değeri 68'dir. Sporcuların ortalama kaygı düzeyi puanından hareketle $(45,91)$, orta düzeyde kaygı düzeyine sahip olduklarını söylemek mümkündür.

Tablo 3. Sporcuların Yaş Değişkenine Göre Antrenör İletişim Beceri Ölçeği (AİBÖ) ve Sürekli Kaygı Ölçeği’ne (SKÖ) İlişkin Kruskal Wallis Testi Sonuçları

\begin{tabular}{|l|l|c|c|c|c|c|c|}
\hline Değişkenler & Yaş & $\mathrm{n}$ & $\begin{array}{c}\text { Sıra } \\
\text { Ortalaması }\end{array}$ & $\mathrm{sd}$ & $\mathrm{x}^{2}$ & $\mathrm{p}$ & $\begin{array}{c}\text { Anlamlı } \\
\text { Fark }\end{array}$ \\
\hline \multirow{5}{*}{ AïBÖ } & 18 ve altı & 87 & 122.09 & & & & - \\
& $19-23$ & 83 & 107.02 & & & & - \\
& $24-28$ & 40 & 118.15 & 4 & 5.640 & .228 & - \\
& $29-33$ & 16 & 132.44 & & & & - \\
& 34 ve üstü & 9 & 153.39 & & & & \\
\hline \multirow{5}{*}{ SKÖ } & 18 ve altı & 87 & 124.29 & & & & - \\
& $19-23$ & 83 & 117.69 & & & & - \\
& $24-28$ & 40 & 115.73 & 4 & 2.581 & .630 & - \\
& $29-33$ & 16 & 96.47 & & & & - \\
\hline
\end{tabular}

Tablo 3 incelendiğinde 'AİBÖ’ ve 'SKÖ’nin sporcuların yaş değişkenine göre anlamlı bir farkl111k gösterip göstermediğini belirlemek amacıyla yapılan kruskal wallis testi sonucunda, AİBÖ ve SKÖ ile yaş değişkeni arasında istatiksel açıdan anlamlı bir farklılık bulunmamıştır ( $\mathrm{p}>0.05)$.

Tablo 4. Sporcuların Cinsiyet Değişkenine Göre "AİBÖ” ve “SKÖ”ne İlişkin Mann Whitney-U Testi Sonuçları

\begin{tabular}{|c|c|c|c|c|c|c|c|}
\hline Değişkenler & Cinsiyet & $n$ & $\begin{array}{c}\text { Sıra } \\
\text { Ortalaması }\end{array}$ & $\begin{array}{c}\text { Sıra } \\
\text { Toplamı }\end{array}$ & $U$ & Z & $p$ \\
\hline \multirow{2}{*}{ AlBÖ } & Erkek & 129 & 114.35 & 14751.00 & \multirow{2}{*}{6366.00} & \multirow{2}{*}{-.908} & \multirow{2}{*}{.364} \\
\hline & Kadın & 106 & 122.44 & 12979.00 & & & \\
\hline \multirow{2}{*}{ SKÖ } & Erkek & 129 & 100.36 & 12947.00 & \multirow{2}{*}{4562.00} & \multirow{2}{*}{-4.393} & \multirow{2}{*}{.00} \\
\hline & Kadın & 106 & 139.46 & 14783.00 & & & \\
\hline
\end{tabular}

Tablo 4 incelendiğinde "AİBÖ” ile sporcuların cinsiyet değişkeni arasında istatiksel olarak anlamlı bir farklılık yok iken ( $\mathrm{p}>0.05$ ), 'SKÖ' ile sporcuların cinsiyet değişkeni arasında anlamlı farklılık bulunmuştur $(\mathrm{p}<0.05)$. Kadın sporcuların kaygı düzeyi $(\mathrm{X}=122,44)$, erkek sporcuların kaygı düzeyinden $(X=114,35)$ daha yoğun olarak yorumlanmıştır.

Tablo 5. Sporcuların Medeni Durum Değişkenine Göre "AİBÖ” ve "SKÖ”ne İlişkin Mann Whitney-U Testi Sonuçları

\begin{tabular}{|l|c|c|c|c|c|c|}
\hline Değişkenler & $\begin{array}{c}\text { Medeni } \\
\text { Durum }\end{array}$ & $\mathrm{n}$ & $\begin{array}{c}\text { Sıra } \\
\text { Ortalaması }\end{array}$ & $\begin{array}{c}\text { Sıra Top- } \\
\text { lamı }\end{array}$ & $\mathrm{U}$ & $\mathrm{p}$ \\
\hline \multirow{2}{*}{ AïBÖ } & Evli & 25 & 149.18 & 3729.50 & \multirow{2}{*}{1845.50} & .015 \\
& Bekâr & 210 & 114.29 & 24000.50 & \\
\hline \multirow{2}{*}{ SKÖ } & Evli & 25 & 111.60 & 2790.00 & \multirow{2}{*}{2465.00} & .618 \\
\cline { 2 - 5 } & Bekâr & 210 & 118.76 & 24940.00 & \\
\hline
\end{tabular}

Tablo 5 incelendiğinde 'AİBÖ' ile sporcuların medeni durumları arasında istatiksel açıdan anlamlı bir farklılık tespit edilmiş ( $\mathrm{p}<0.05)$, 'SKÖ’ ile sporcuların medeni durumları arasında 
ise, anlamlı bir farklılık bulunmamıştır ( $\mathrm{p}>0.05$ ). Tablo 5'e göre sıra ortalamalarından hareketle, evli sporcuların bekar sporculara göre antrenörlerinin iletişim becerilerini daha yüksek seviyede algıladığını söylemek mümkündür.

Tablo 6. Sporcuların Eğitim Durumuna Göre “AIBÖ̈" ve "SKÖ"ne İlişkin Kruskal Wallis Testi Sonuçları

\begin{tabular}{|c|c|c|c|c|c|c|c|}
\hline Değişkenler & $\begin{array}{l}\text { Eğitim } \\
\text { Durumu }\end{array}$ & $\mathrm{n}$ & $\begin{array}{c}\text { Sıra } \\
\text { Ortalaması }\end{array}$ & sd & $x^{2}$ & $p$ & $\begin{array}{l}\text { Anlamlı } \\
\text { Fark }\end{array}$ \\
\hline AlBÖ & $\begin{array}{l}\text { Ortaöğre- } \\
\text { tim } \\
\text { Lisans } \\
\text { Lisansüstü }\end{array}$ & $\begin{array}{c}57 \\
162 \\
16\end{array}$ & $\begin{array}{l}120.70 \\
116.88 \\
119.75\end{array}$ & 2 & .145 & .930 & $\begin{array}{l}- \\
- \\
-\end{array}$ \\
\hline SKÖ & $\begin{array}{l}\text { Ortaöğre- } \\
\text { tim } \\
\text { Lisans } \\
\text { Lisansüstü }\end{array}$ & $\begin{array}{c}57 \\
162 \\
16\end{array}$ & $\begin{array}{l}111.46 \\
121.91 \\
101.66\end{array}$ & 2 & 1.994 & .369 & 5 \\
\hline
\end{tabular}

Tablo 6 incelendiğinde "AİBÖ" ve "SKÖ”nin sporcuların eğitim durumu değişkenine bağlı olarak farklılık gösterip göstermediğini belirlemek amacıyla yapılan kruskal wallis testi sonucunda, AİBÖ ve SKÖ ile eğitim durumu değişkeni arasında istatiksel olarak anlamlı farklılık bulunmamıştır ( $\mathrm{p}>0.05)$.

Tablo 7. Sporcuların branş değişkenine göre "AIBBÖ” ve "SKÖ"ne İliş̧kin Verilerin Saptanması İçin Mann Whitney-U Testi Sonuçları

\begin{tabular}{|l|l|c|c|c|c|c|c|}
\hline \multirow{2}{*}{ Değişkenler } & $\begin{array}{l}\text { Spor } \\
\text { Branşı }\end{array}$ & $\mathrm{n}$ & $\begin{array}{c}\text { Sıra } \\
\text { Ortalaması }\end{array}$ & $\begin{array}{c}\text { Sıra } \\
\text { Toplamı }\end{array}$ & $\mathrm{U}$ & $\mathrm{Z}$ & $\mathrm{p}$ \\
\hline \multirow{2}{*}{ AiBÖ } & Basketbol & 126 & 124.01 & 15625.50 & \multirow{2}{*}{6109.50} & -1.458 & .145 \\
& Voleybol & 109 & 111.05 & 12104.50 & & \\
\hline \multirow{2}{*}{ SKÖ } & Basketbol & 126 & 102.83 & 12956.00 & \multirow{2}{*}{4955.00} & -3.684 & \multirow{2}{*}{.00} \\
\cline { 2 - 7 } & Voleybol & 109 & 135.54 & 14774.00 & & & \\
\hline
\end{tabular}

Tablo 7 incelendiğinde 'AİBÖ' ile sporcuların branş değişkeni arasında istatiksel açıdan anlamlı farklılık tespit edilmezken ( $\mathrm{p}>0.05)$, 'SKÖ’ ile sporcuların branş değişkeni arasında anlamlı farklılık bulunmuştur $(\mathrm{p}<0.05)$. Branş bazında sporcuların ortalama kaygı ölçek puanları incelendiğinde, voleybol sporcularının kaygı düzeylerinin $(X=135.54)$ basketbol sporcularının kaygı düzeyine ( $\mathrm{X}=102.83)$ göre daha yüksek olduğunu söylemek mümkündür.

Tablo 8. Sporcuların Spor Yapma Süresi Değişkenine Göre “AIBÖ” ve "SKÖ”ne Illişkin Kruskal Wallis Testi Sonuçlarl

\begin{tabular}{|c|c|c|c|c|c|c|c|}
\hline Değişkenler & $\begin{array}{l}\text { Spor Yapma } \\
\text { Süresi (Yıl) }\end{array}$ & $\mathrm{n}$ & $\begin{array}{c}\text { Sıra } \\
\text { Ortalaması }\end{array}$ & sd & $x^{2}$ & $p$ & $\begin{array}{l}\text { Anlamlı } \\
\text { Fark }\end{array}$ \\
\hline AİBÖ & $\begin{array}{l}7 \text { yıl ve altı } \\
8-14 \text { yıl } \\
15-21 \\
22 \text { ve üstü }\end{array}$ & $\begin{array}{c}57 \\
123 \\
46 \\
9\end{array}$ & $\begin{array}{l}114.93 \\
107.96 \\
145.29 \\
135.11\end{array}$ & 3 & 10.785 & .013 & $1-4$ \\
\hline SKÖ & $\begin{array}{l}7 \text { yıl ve altı } \\
8-14 \text { yıl } \\
15-21 \\
22 \text { ve üstü }\end{array}$ & $\begin{array}{c}57 \\
123 \\
46 \\
9\end{array}$ & $\begin{array}{c}122.26 \\
123.54 \\
96.52 \\
125.06\end{array}$ & 3 & 5.746 & .125 & $\begin{array}{l}- \\
- \\
-\end{array}$ \\
\hline
\end{tabular}

Tablo 8 incelendiğinde “AİBÖ” ve "SKÖ"nin sporcuların spor yapma yılı değişkenine göre anlamlı farklılık gösterip göstermediğini belirlemek amacıyla yapılan kruskal wallis testi sonucunda, AİBÖ ile spor yapma süresi arasında anlamlı farklılık tespit edilmiştir. Grupların ortalamaları dikkate alındığında, antrenör iletişim becerisini 22 yıl ve üstü sporcu geçmişi bulunan sporcular, 7 yıl ve altında sporcu geçmişi bulunanlara göre daha üst düzeyde algılamaktadır $(p<0.05)$, SKÖ ile sporcuların spor yapma süresi değişkeni arasında istatiksel olarak anlamlı farklılık bulunmamıştır ( $\mathrm{p}>0.05)$. 
Tablo 9. Sporcuların Mevcut Antrenörleri Çalışma Zamanına Göre “AIBÖ̈”ve “SKÖ”ne İlişkin Kruskal Wallis Testi Sonuçları

\begin{tabular}{|l|l|c|c|c|c|c|c|}
\hline \multirow{2}{*}{ Değişkenler } & $\begin{array}{l}\text { Mevcut Antrenör İle } \\
\text { Çalışma Süresi (Ay) }\end{array}$ & $\mathrm{n}$ & $\begin{array}{c}\text { Sıra } \\
\text { Ortalaması }\end{array}$ & sd & $\mathrm{x}^{2}$ & $\mathrm{p}$ & $\begin{array}{c}\text { Anlamlı } \\
\text { Fark }\end{array}$ \\
\hline \multirow{4}{*}{ AïBÖ } & 12 ve altı & 130 & 112.48 & & & & - \\
& $13-36$ & 72 & 121.01 & \multirow{2}{*}{3} & 2.690 & .442 & - \\
& $37-60$ & 17 & 130.50 & & & & \\
& 60 ve üstü & 16 & 135.97 & & & & \\
\multirow{5}{*}{ SKÖ } & 12 ve altı & 130 & 122.10 & & & & - \\
& $13-36$ & 72 & 111.14 & \multirow{2}{*}{3} & 2.636 & .451 & - \\
& $37-60$ & 17 & 103.18 & & & & \\
\hline
\end{tabular}

Tablo 9 incelendiğinde "AİBÖ" ve "SKÖ”nin sporcuların mevcut antrenörleri ile çalışma zamanı değişkenine göre anlamlı farklılık gösterip göstermediğini belirlemek amacıyla yapılan kruskal wallis testi sonucunda, AİBÖ ve SKÖ ile mevcut antrenör ile çalışma süresi değişkeni arasında istatiksel olarak anlamlı farklılık bulunmamıştır ( $\mathrm{p}>0.05)$.

Tablo 10. Antrenörlerin Illetişim Beceri Düzeyi ile Sporcuların Sürekli Kaygı Düzeyi Puanlarının Pearson Momentler Çarpımı Korelasyon Katsayısı Sonuçları

\begin{tabular}{|l|c|c|}
\hline Değişkenler & AïBÖ & SKÖ \\
\hline Al̈Ö & - & .469 \\
SKÖ & & - \\
\hline $\mathrm{N}=235$ & $\mathrm{p}>$.05 \\
\hline
\end{tabular}

Tablo 10 incelendiğinde antrenörlerin iletişim beceri düzeyleri ile sporcuların kaygı durumları arasında anlamlı bir ilişki bulunmamaktadır ( $>0.05)$.

Tablo 11. Sürekli Kaygı Düzeyinin Yordanmasına İlişkin Çoklu Regresyon Analizi Sonuçları

\begin{tabular}{|c|c|c|c|c|c|c|c|}
\hline Değişkenler & B & Standart Hata & $\beta$ & $\mathrm{T}$ & $\mathrm{p}$ & $\underset{r}{\text { İkili }}$ & $\begin{array}{c}\text { Kismi } \\
\text { R }\end{array}$ \\
\hline Sabit & 42,736 & 4,730 & - & 9,034 & ,000 & - & - \\
\hline Yaş &,- 905 & 678 &,- 144 & $-1,334$ & , 184 &,- 091 &,- 088 \\
\hline Cinsiyet & $-2,485$ & ,990 &,- 182 & $-2,510$ & ,013 & -.245 &,- 164 \\
\hline Medeni Durum & $-1,110$ & 1,697 &,- 051 &,- 654 & ,514 & ,020 &,- 043 \\
\hline Eğitim Düzeyi & 1,879 & ,918 & 147 & 2,048 & ,042 & ,062 & ,135 \\
\hline Spor Branşı & 1,840 & ,988 & , 135 & 1,862 & ,064 & ,216 & ,123 \\
\hline $\begin{array}{l}\text { Spor Yapma } \\
\text { Zamanı }\end{array}$ & ,118 & ,836 & ,013 & ,142 & ,888 &,- 079 & ,009 \\
\hline $\begin{array}{l}\text { Antrenörle } \\
\text { Çalışma Zamanı }\end{array}$ & , 155 & ,499 & ,020 & ,311 & ,756 &,- 041 & ,021 \\
\hline
\end{tabular}

Tablo 11 incelendiğinde, yaş, cinsiyet, medeni durum, eğitim düzeyi, spor branş1, spor yapma zamanı, antrenörle çalışma zamanı değişkenleri birlikte, sporcuların sürekli kaygı düzeyi puanları ile anlamlı bir ilişki vermektedir $\left(\mathrm{r}=0.305, \mathrm{R}^{2}=0.093, \mathrm{p}<.01\right)$. Mevcut yedi değişken birlikte, sürekli kaygı düzeyindeki varyansın \% 9'unu oluşturmaktadır.

Standardize edilmiş regresyon katsayısına $(\beta)$ göre, yordayıcı değişkenlerin sürekli kaygı düzeyi üzerindeki göreli önem sırasi; cinsiyet, eğitim düzeyi, spor branş1, yaş, medeni durum, antrenörler çalışma zamanı ve spor yapma zamanıdır. Regresyon katsayılarının anlamlılığına ilişkin t-testi sonuçları incelendiğinde ise, cinsiyet ve eğitim düzeyi değişkenlerinin sürekli kaygı düzeyi üzerinde anlamlı bir yordayıcı olduğu görülmektedir. Yaş, medeni durum, spor branş1, spor yapma zamanı ve antrenörle çalışma zamanı değişkenleri önemli bir etkiye sahip değildir. 
Tablo 12. Antrenör İletişim Beceri Düzeyinin Yordanmasına İlişkin Çoklu Regresyon Analizi Sonuçları

\begin{tabular}{|l|c|c|c|c|c|c|c|}
\hline Değişkenler & B & $\begin{array}{c}\text { Standart } \\
\text { Hata }\end{array}$ & $\beta$ & $\mathrm{T}$ & $\mathrm{p}$ & $\begin{array}{c}\text { Ikili } \\
\mathrm{r}\end{array}$ & $\begin{array}{c}\text { Kısmi } \\
\mathrm{R}\end{array}$ \\
\hline Sabit & 238,420 & 21,350 & - & 11,167 &, 000 & - & - \\
\hline Yaş & $-5,262$ & 3,062 &,- 186 & $-1,719$ &, 087 &, 033 &,- 113 \\
\hline Cinsiyet & $-11,694$ & 4,468 &,- 191 & $-2,617$ &, 009 &,- 103 &,- 171 \\
\hline Medeni Durum & $-16,551$ & 7,660 &,- 168 & $-2,161$ &, 032 &,- 139 &,- 142 \\
\hline Eğitim Düzeyi & $-2,573$ & 4,142 &,- 045 &,- 621 &, 535 &,- 037 &,- 041 \\
\hline Spor Branşı & $-7,107$ & 4,459 &,- 117 & $-1,594$ &, 112 &,- 063 &,- 105 \\
\hline $\begin{array}{l}\text { Spor Yapma } \\
\text { Zamanı }\end{array}$ & 7,975 & 3,775 &, 201 & 2,112 &, 036 &, 111 &, 139 \\
\hline $\begin{array}{l}\text { Antrenörle } \\
\text { Çalışma Zamanı }\end{array}$ & 4,712 & 2,251 &, 137 & 2,093 &, 037 &, 111 &, 138 \\
\hline
\end{tabular}

Tablo 12 incelendiğinde, yaş, cinsiyet, medeni durum, eğitim düzeyi, spor branş1, spor yapma zamanı, antrenörle çalışma zamanı değişkenleri birlikte, antrenörlerin iletişim beceri düzeyi puanları ile anlamlı bir ilişki vermektedir $(\mathrm{r}=0.289, \mathrm{R} 2=0.083, \mathrm{p}<.01)$. Mevcut yedi değişken birlikte, antrenör iletişim beceri düzeyindeki varyansın \% 8'ini oluşturmaktadır.

Standardize edilmiş regresyon katsayısına $(\beta)$ göre, yordayıcı değişkenlerin antrenör iletişim beceri düzeyi üzerindeki göreli önem sırası; cinsiyet, medeni durum, spor yapma zamanı, antrenörle çalışma zamanı, yaş, spor branşı ve eğitim düzeyidir. Regresyon katsayılarının anlamlılığına ilişkin t-testi sonuçları incelendiğinde ise, cinsiyet, medeni durum, spor yapma zamanı ve antrenörle çalışma zamanı değişkenlerinin antrenör iletişim beceri düzeyi üzerinde anlamlı bir yordayıcı olduğu görülmektedir. Yaş, eğitim düzeyi ve spor branşı değişkenleri önemli bir etkiye sahip değildir.

\section{Tartışma ve Sonuç}

$\mathrm{Bu}$ araştırma Türkiye Basketbol Federasyonu ve Türkiye Voleybol Federasyonu'nun profesyonel liglerinde mücadele eden takımların antrenörlerinin iletişim beceri düzeyleri ile sporcuların kaygı düzeyi üzerinde etkili olabilecek değişkenlerin belirlenmesi amacıyla yapılmıştır.

Araştırmaya katılan 235 sporcunun büyük bir çoğunluğunun 23 yaş ve altında olduğu, lisans seviyesinde eğitim düzeyinde ve spor branşları ile ilgilenme sürelerinin 8-14 yıl arasında değiştiği görülmüş; sporcuların kaygı düzeyinin ortalama düzeyde seyrettiği, antrenörlerin iletişim beceri düzeyinin üst seviyede olduğu belirlenmiştir.

Sporcuların kaygı düzeyinin orta düzeyde olması, antrenör iletişim beceri düzeyinin yüksek düzeyde olmasından kaynaklandığı düşünülmektedir. Antrenörüyle sağlıklı ve açık bir iletişim kurabilen sporcuların kaygı ve endişe düzeylerinde azalma beklenmektedir (Martin ve Mack, 1996, 76-80).

Araştırmaya dair elde edilen bulgular bölümünde, antrenörlerin iletişim beceri düzeyi ile sporcuların medeni durum ve spor yapma süresi değişkenleri arasında anlamlı farklılık tespit edilmiş; yaş, cinsiyet, eğitim düzeyi, spor branşı ve mevcut antrenör ile çalışma süresi değişkenleri arasında farklılık tespit edilmemiştir. Medeni durumu evli olan sporcular bekar sporculara göre, 22 yıl ve üzeri sporcu geçmişi bulunan sporcular ise, 7 yıl ve altı sporcu geçmişi bulunanlara göre antrenörlerin iletişim becerisini daha üst düzeyde değerlendirmiştir.

Evli bireylerin toplumsal hayatta daha fazla sorumluluk sahibi olması, diğer insanlarla daha etkin iletişim kurmalarına neden olabilir. Spor yapma süresi artıkça; antrenman ve müsabaka şartları, hakemler, takım arkadaşları, diğer sporcularla olan etkileşim ve diğer somut ve soyut etkenler ile sporcuların bunlarla başa çıkma stratejilerinin de geliştiği düşünülmektedir. $\mathrm{Bu}$ durum, iletişim becerilerinin de artmasına neden olabilir. 
Sporcuların sürekli kaygı düzeyi ile sporcuların cinsiyet ve spor branşı değişkenleri arasında anlamlı farklılık tespit edilmiş; yaş, medeni durum, eğitim düzeyi, spor yapma süresi ve mevcut antrenör ile çalışma süresi değişkenleri arasından farklılık tespit edilmemiştir. Voleybol branşı ile ilgilenen sporcuların kaygı düzeyinin, basketbol sporu ile ilgilenen sporcuların kaygı düzeyine göre ve kadın sporcuların kaygı düzeyinin, erkek sporcuların kaygı düzeyine göre daha yüksek olduğu tespit edilmiş, aralarındaki fark istatiksel açıdan anlamlı bulunmuştur.

Ülkemizde ve dünyada genellikle erkek antrenörlerin takımların başında görev alması ve kadın antrenörlerin erkeklere göre daha yüksek seviyede empatik yaklaşıma sahip olması (Öztürk ve diğerleri, 2004), kadın sporcuların kaygı düzeyini artıran bir etmen olarak düşünülmektedir. Kadın sporcuların erkek sporculara göre sporda dayanıklılık seviyelerinin daha alt seviyede olması da kaygı düzeyini farklılaştıran bir unsur olarak düşünülmektedir. Jones ve diğerleri (1993, 528-530), sporcuların kayg1 düzeyinin performansları üzerinde önemli bir etkiye sahip olduğunu belirtmiştir. Anshel ve Wells (2000, 1-7), spor ortamında karşıllklı anlaşmazlıklar, hakem kararları, bireysel performanslar, karşılıklı etkileşim ve takım içerisindeki davranışların sporcuların kaygı düzeyine etki eden unsurlar olduğunu belirtmiştir. Açıkada ve Ergen (1990, 141-146), bireyin psikolojik gerilim durumunda kassal gerilime de maruz kalacağını ifade etmiştir. Bu noktadan hareketle kaygının sportif alanda negatif etki yaratabileceği düşünülebilir. Antrenörlerin, sporcuların kaygı düzeylerini en aza indirgeyecek tedbirler ile birlikte, spor psikologlarından da destek almaları yararlı olabilir.

Selağzı ve Çepikkurt $(2014,15)$, antrenör ve sporcu arası iletişim düzeylerinin belirlenmesine yönelik yaptığı çalışmasında cinsiyet değişkenine göre farklılık tespit etmemiştir. Bayrak ve Nacar $(2015,397)$; futbol, voleybol, basketbol ve hentbol antrenörlerinin iletişim beceri düzeylerinin belirlenmesine yönelik yaptı̆̆ çalışmasında, voleybol antrenörlerinin iletişim becerilerini daha yüksek bulurken, basketbol antrenörlerini diğer branşlara göre daha başarısız bulmuştur. Yılmaz ve diğerleri $(2009,55)$, bireysel ve takım sporlarında görev yapan antrenörlerin iletişim beceri düzeylerini karşılaştırdığ 1 araştırmasında; bireysel sporlarda görev yapan antrenörleri, takım sporlarında görev yapan antrenörlere göre daha başarılı bulmuştur. Ayrıca takım sporları içerisinde, voleybol takımı antrenörlerinin iletişim becerilerini, futbol ve hentbol antrenörlerinden daha yüksek seviyede olduğunu tespit etmiştir.

Türkçapar'ın $(2012,135)$ çalışmasında güreş sporuyla ilgilenen sporcuların sürekli kaygı düzeylerinin yaş değişkenine göre farklılaşmadığı, Karabulut ve diğerlerinin (2013, 247) araştırmasında 13-15 yaş arası erkek futbolcuların spor yapma süresine göre sürekli kaygı̈ düzeylerinin farklılık göstermemesi mevcut çalışmayı destekler nitelikte iken, Civan ve diğerlerinin $(2010,199)$ çalışmasında sporcuların sürekli kaygı düzeylerinin cinsiyet değişkenine göre farklı1ık göstermemesi mevcut araştırma ile benzerlik teşkil etmemektedir.

Araştırma bulgularında, antrenör iletişim beceri düzeyi, sporcuların demografik özelliklerinden cinsiyet, medeni durum, spor yapma süresi ve mevcut antrenör ile çalışma süresi değişkenleri puanları üzerinde anlamlı bir ilişki göstermektedir $(r=0.289, \mathrm{R} 2=0.083, \mathrm{p}<.01)$. Yaş, eğitim düzeyi ve spor branşı değişkenlerinin önemli bir etkiye sahip olmadığı tespit edilmiştir. Ayrıca sürekli kaygı düzeyi ile, sporcuların demografik özelliklerinden cinsiyet ve eğitim düzeyi değişkenleri arasında anlamlı bir ilişki görülmektedir $\left(r=0.305, \mathrm{R}^{2}=0.093, \mathrm{p}<.01\right)$. Yaş, medeni durum, spor branşı, spor yapma zamanı ve antrenörle çalışma zamanı değişkenlerinin önemli bir etkiye sahip olmadığı belirlenmiştir.

$\mathrm{Bu}$ araştırmada sporcuların kaygı düzeyi ve antrenörlerin iletişim beceri düzeylerinin, sporcuların demografik özellikleri ile ilişkili olduğu bulunmasına rağmen, sporcuların sürekli kayg1 düzeyi ile antrenörlerin iletişim beceri düzeyleri arasında anlamlı bir ilişki tespit edilmemiştir. Bununla beraber sporcu kaygı düzeyi ile antrenör iletişim becerisi arasındaki ilişkinin farklı örneklemlerde test edilmesi farklı sonuçları ortaya çıkarabilir. 


\section{Kaynakça}

Abakay, U. ve Kuru, E. (2011a). Profesyonel ve Amatör Futbolcuların Antrenörleri ile Olan İletişim Düzeyi Farklı1ıklarının Karşılaştııılması. Selçuk Üniversitesi Beden Eğitimi ve Spor Bilimleri Dergisi, 13(1), 125-131.

Abakay, U. ve Kuru, E. (2013b). Kadın Futbolcularda Antrenörle İletişim Düzeyi ve Başarı Motivasyonu İlişkisi. Gaziantep University Journal of Sport Sciences, 12(1), 20-33.

Açıkada, C. ve Ergen, E. (1990). Bilim ve Spor. İstanbul: TEK Ofset Matbaacılık.

Anshel, M. S. ve Wells B. (2000). Sources of acute stress and coping styles in competitive sport [Rekabet Sporunda Akut Stres Kaynakları ve Başa Çıkma Stratejileri]. Anxiety, Stress, \& Coping, 13(1), 1-26.

Atasoy, B. ve Kuter, F.,Ö. (2005). Küreselleşme ve Spor. Eğitim Fakültesi Dergisi, 18(1), 11-22.

Bahar, E. (2012). Iletişsim. Ankara: Detay Yayıncılık.

Bayrak, E. ve Nacar, E. (2015). Profesyonel Takım Sporlarında Görev Yapan Antrenörlerin İletişim Beceri Düzeylerinin Araştırılması. Akademik Sosyal Araştırmalar Dergisi, 3(14), 391-405.

Bilgin, L. (2010). Halkla İlişkiler. (2. bs.). İstanbul: Kum Saati Yayınları.

Büyüköztürk, Ş. (1997). Araştırmaya Yönelik Kayg1 Ölçeğinin Geliştirilmesi. Kuram ve Uygulamada Eğitim Yönetimi Dergisi, 3(4), 453-464.

Civan, A., Arı, R., Görücü, A. ve Özdemir, M. (2010). Bireysel ve Takım Sporcularının Müsabaka Öncesi ve Sonrası Durumluk ve Sürekli Kayg1 Düzeylerinin Karşılaştırılması. Uluslararası Ínsan Bilimleri Dergisi, 7(1), 193-206.

Cüceloğlu, D. (1999). İnsan ve Davranışı. (9. bs.). İstanbul: Remzi Kitabevi.

Coşkun, Y. ve Akkaş, G. (2009). Engelli Çocuğu Olan Annelerin Sürekli Kaygı Düzeyleri ile Sosyal Destek Algıları Arasındaki İlişki. Ahi Devran Üniversitesi Kırşehir Eğitim Fakültesi Dergisi, 10(1), 213-227.

Çetin, N. (2013). Toplum Sağllğgl Için Spor. (2. bs.). İstanbul: Turna Yayınları.

Çetinkaya, Z. (2011). Türkçe Öğretmen Adaylarının İletişim Becerilerine İlişkin Görüşlerinin Belirlenmesi. Kastamonu Eğitim Dergisi, 19(2), 567-576.

Demirtaş, M. (2010). Örgütsel İletişimin Verimlilik ve Etkinliğinde Yararlanılan İletişim Araçları ve Halkla İlişkiler Filmleri Örneği. Marmara Üniversitesi İktisadi ve İdari Bilimler Fakültesi Dergisi, 28(1), 411-444.

Doğan, B. (2007). Spor Sosyolojisi ve Uygulamalı Spor Sosyolojisine Giriş. Ankara: Nobel Yayın Dağıtım.

Güngör, N. (2013). İletişim Kuramlar ve Yaklaşımlar. (2. bs.). Ankara: Siyasal Kitabevi.

Işık, M. (2013). Illetişim ve Etik. Konya: Eğitim Yayınları.

İşler, H. (2012). Beden Eğitimi ve Spor Bilgileri Rehber Kitabı. İstanbul: Bedray Yayınları.

Jones, G., Swain, A., ve Hardy, L. (1993). Intensity and direction dimensions of competitive state anxiety and relationships with performance [Rekabetçi Durum Kaygısının Yoğunluk ve Yön Boyutları İle Performansla İlişkisi]. Journal of Sports Sciences, 11(6), 525-532. 
Kabaday1, Ş. (2010). Hentbol Antrenörlerinin İletişim Becerilerinin Değerlendirilmesi (Hentbol Süper Lig Örneği). Doktora tezi, Anadolu Üniversitesi, Eskişehir.

Karabulut, E. O., Atasoy, M., Kaya, K. ve Karabulut, A. (2013). 13-15 Yaş Arası Erkek Futbolcuların Durumluk ve Sürekli Kaygı Düzeylerinin Farklı Değiş̧kenler Bakımından İncelenmesi. Ahi Evran Üniversitesi Kırşehir Eğitim Fakültesi Dergisi, 14(1), 243253.

Karasar, N. (2014). Bilimsel Araştırma Yöntemi. Ankara: Nobel Yayın Dağıtım.

Martin, K, A. ve Mack, D. (1996). Relationships between physical self-presentation and sport competition trait anxiety: a preliminary study [Fiziksel Kendini Tanıma ve Sporda Müsabaka Kaygısı Arasındaki İlişkiler: Bir Ön Çalışma]. Journal of Sport Exercise Psychology, 18(1), 75-82.

Mutlu, E. (2012). Iletişsim Sözlüğ̈̈. (6. bs.). Ankara: Sofos.

Öner, N. ve Le Compte, A. (1983). Durumluk-Sürekli Kaygl Envanteri El Kitabı. İstanbul: Boğaziçi Üniversitesi Yayınları.

Öztürk, F., Koparan, Ş., Haş11, N., Efe, M. ve Özkaya, G. (2004). Antrenör ve hakemlerin empati durumlarının araştırılması. SPORMETRE Beden Eğitimi ve Spor Bilimleri Dergisi, 2(1), 19-25.

Selağzı, S. ve Çepikkurt, F. (2014). Antrenör ve Sporcu İletişim Beceri Düzeylerinin Belirlenmesi. CBÜ Beden Ĕgitimi ve Spor Bilimleri Dergisi, 9(1), 11-18.

Singer, M. G. (1990). Human Resource Management. Boston: PSW-KENT Publishing.

Spielberger, C. D., Gorsuch, R.L. ve Lushene, R. E. (1970). Manual for the state-trait anxiety invenntory. California: Consulting Psychologists Press.

Şahin, A. (2007). Türk Kamu Yönetiminde Yönetsel İletişim ve Bu Konuda Düzenlenen Bir Anket Çalışmasının Sonuçları. Maliye Dergisi, 152, 81-102.

Tosun, Ö. Ç. (2014). Iliş̧kilerde Yaşanan Kaygllar. Erişim: 14 Kasım 2015, Pinna Psikoloji Ağ Sitesi: https://www.pinnapsikoloji.com/\#!kaygi-ve-iliskiler/c1axq

Türkçapar, Ü. (2012). Güreşçilerin Farklı Değişkenler Açısından Sürekli Kaygı Düzeylerinin İncelenmesi. Gazi Üniversitesi Gazi Eğitim Fakültesi Dergisi, 32(1), 129-140.

Yetim, A. A. ve Cengiz, R. (2012). İletişim ve Spor. (2. bs.). Ankara: Berikan Yayınevi.

Yılmaz, İ. (2008). Sporcu Algıları Çerçevesinde Farklı Spor Branşlarındaki Antrenörlerin Liderlik Davranış Analizleri ve İletişim Beceri Düzeyi. Doktora tezi, Gazi Üniversitesi, Ankara.

Yılmaz, İ., Çimen, Z. ve Bektaş, F. (2009). Sporcu Algılamalarına Göre Bireysel ve Takım Sporu Antrenörlerinin İletişim Beceri Düzeylerinin Karşılaştırılması. Atatürk Üniversitesi Beden Eğitimi ve Spor Bilimleri Dergisi, 11(4), 52-57. 